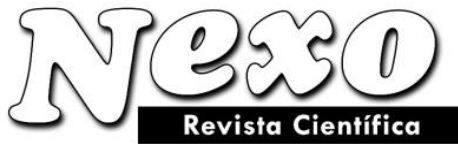

ISSN-E 1995-9516

Universidad Nacional de Ingeniería COPYRIGHT @ (UNI). TODOS LOS DERECHOS RESERVADOS http://revistas.uni.edu.ni/index.php/Nexo https://doi.org/10.5377/nexo.v34i04.12640

Vol. 34, No. 04, pp. 1148-1163/Septiembre 2021

(c) (i) () $\Theta$

\title{
3D Inversion of Airborne Magnetic Data and Validation of it by Using Sourk Mine Drilling Data
}

\section{Inversión 3D de Datos Magnéticos Aerotransportados y su Validación Mediante el Uso de Datos de Perforación de la Mina Sourk}

\author{
Omid Amani Jafarlou ${ }^{1}$, Afshin Ashja Ardalan ${ }^{1 *}$, Ahmad Adib $^{2}$, Alireza Ganji ${ }^{3}$, Soheila Bouzari $^{1}$ \\ ${ }^{1}$ Department of Geology, North Tehran Branch, Islamic Azad University, Tehran, Iran. \\ ${ }^{2}$ Department of Petroleum Engineering, South Tehran Branch, Islamic Azad University, Tehran, \\ Iran. \\ ${ }^{3}$ Department of Geology, Lahijan Branch, Islamic Azad University, Lahijan, Iran.
}

Afshinashjaardalan@yahoo.com

(recibido/received: 23-mayo-2021; aceptado/accepted: 13-agosto-2021)

\begin{abstract}
The airborne magnetic method is one of the most significantly applied approaches in mineral exploration. This magnetic method has been widely used in recent years due to its extensive coverage, lower cost than other methods and coverage of impassable areas and forests. For many years in Iran, the magnetic method has been utilized by authorities to survey ore deposits and to prepare structural and geological maps. This paper presents part of the Dehshir area exploration data of airborne surveys by helicopter with flight line spacing of 250 meters and flight height of 40 meters conducted by Geological Survey and Mineral Exploration of Iran. Furthermore, among the potential areas in the Dehshir area is the studied hereby area of Block C2 of Sourk mine. This region in Yazd province with a $4.1 \mathrm{~km}^{2}$ area is located at $95 \mathrm{~km}$ northwest of Yazd city. The purpose of this paper is to present a three-dimensional model of magnetic data and its validation using drilling data. The three-dimensional modeling of magnetic data has been processed by Inversion method. Next, the locations of boreholes were proposed for drilling. Then, the boreholes data is used to evaluate the geophysical method model by comparing the three-dimensional modeling of magnetic data and three-dimensional modeling of the proposed drilled boreholes data.
\end{abstract}

Keywords: Airborne Magnetic, Inversion, Boreholes, Susceptibility, Sourk Mine, Iron Skarn.

\section{RESUMEN}

El método magnético aerotransportado es uno de los enfoques más aplicados en la exploración minera. Este método magnético ha sido ampliamente utilizado en los últimos años debido a su amplia cobertura, menor costo que otros métodos y cobertura de áreas intransitables y bosques. Durante muchos años en Irán, las autoridades han utilizado el método magnético para estudiar los 
depósitos de mineral y preparar mapas estructurales y geológicos. Este documento presenta parte de los datos de exploración del área de Dehshir de reconocimientos aéreos por helicóptero con un espaciado de línea de vuelo de 250 metros y una altura de vuelo de 40 metros realizados por el Servicio Geológico y Exploración Mineral de Irán. Además, entre las áreas potenciales en el área de Dehshir se encuentra el área estudiada del Bloque C2 de la mina Sourk. Esta región en la provincia de Yazd con un área de 4,1 km2 se encuentra a $95 \mathrm{~km}$ al noroeste de la ciudad de Yazd. El propósito de este artículo es presentar un modelo tridimensional de datos magnéticos y su validación utilizando datos de perforación. El modelado tridimensional de datos magnéticos se ha procesado mediante el método de inversión. A continuación, se propuso la ubicación de los pozos para la perforación. Luego, los datos de los pozos se utilizan para evaluar el modelo del método geofísico comparando el modelado tridimensional de los datos magnéticos y el modelado tridimensional de los datos de los pozos perforados propuestos.

Palabras clave: Magnético aéreo, Inversión, Perforaciones, Susceptibilidad, Mina Sourk, Skarn de Hierro.

\section{INTRODUCTION}

Magnetic surveys have been utilized for many years worldwide for indirect exploration. Airborne magnetic method is one of the oldest geophysical methods that have been used for high operational speed and vast coverage reducing the cost of exploration surveys of unexposed ore deposits, especially deposits with magnetic properties. Furthermore, it has reaped the benefit of determining geological structures and the depth of rock and sediments. Moreover, airborne magnetic data has been beneficial in mapping deep structures and their contacts for oil and gas exploration and hydrocarbon resources. With the advancement of data collection devices, data processing systems, high rate of data analysis as well as mapping the structures of the Earth's crust on different scales from bedrock with high magnetic intensity on a regional scale to sedimentary contact with very low intensity on local scale has been achieved (Oldenburg, \& Pratt, 2007). This geophysical method is effective thanks to the effects of geomagnetic field on rocks. The elements of geomagnetic field include three components, $\mathrm{Bx}, \mathrm{By}$, and $\mathrm{Bz}$ in three directions. Also Inclination is the vertical angel between the horizontal plane and the vector, and declination is the azimuth of the magnetic meridian which is positive to the east and negative to the west. The international geomagnetic reference field (IGRF) is calculated based on harmonic terms of the geomagnetic field equations (Blakely, 1995; Baratian et al. 2020; Yazdi et al. 2019; Moghadam et al. 2021). 99\% of the Earth's magnetic field has internal origin which is considered the main field and changes relatively slow and the remaining one percent has external origin that change relatively quick. The main field changes are caused by local magnetic anomalies resulting from changes in the rocks' magnetic mineral content near the Earth's crust surface. These magnetic field changes would be related to local anomalies which can be interpreted concerning the local geological structures. Magnetic methods are used to map changes in susceptibility differences, exploration of ore deposits, the origin of mineral deposits, estimation of rock depth, identification of boundaries of rock units, detection of cracked zones, and finding faults and discontinuities (Oldenburg, \& Pratt, 2007; Yazdi and Sharifi Teshnizi 2021). In this paper accuracy of airborne magnetic data geomodeling is validated by three-dimensional modeling of boreholes data of Sourk mine located in Yazd province. The airborne magnetic data has been surveyed by flight line spacing of 250 meters and flight height of 40 meters using a single sensor helicopter. 


\section{METHODOLOGY}

\subsection{Geological Setting}

The study area is located in northwest of Yazd province. The area is part of central Iran's structural zone near the magmatic-volcanic arc of Orumiyeh-Poldokhtar which has caused various metallic mineralization including iron occurrence here and all along the Dehshir fault zone. The area is between complex of ophiolitic mélanges and volcanic, volcanic-clastic rocks related to Eocene era. (Shafaii Moghadam, Stern, \& Rahgoshay, 2010; Bazoobandi et al. 2016). Due to the widespread coverage of sediments of the present period with alluvial, sand, and deposits left by erosions, only limited outcrops are observable. Mineralization is occurred along the northwest-southeast in form of lenses and veins on the boundary between Eocene volcanic rocks and Granitoid intrusive body. Sourk skarn has outcrop in the vicinity of the ophiolitic complex (along the Dehshir zone); the granodiorite intrusive masses in volcanic and Eocene related pyroclastic (host rock) have brought about mineralization of iron skarn deposit (Makkizadeh, Rahgoshay, \& Daliran, 2007; Ullah et al. 2021; Adewumi et al. 2021). In this study, three main types of lithology have been observed, including iron ore, iron skarns, and tuffs. The primary ore of this mine has magnetite, hematite and pyrite minerals. The most significant mineral is magnetite with abundance of up to $70 \%$. The zoning in Sourk iron skarn is similar to zoning of metamorphic skarns residual of chemical contact type with magma replacement. The presence of garnet, pyroxene, epidote and magnetite is evidence to prove it (Reihany, Noori, Karimi, \& Ghetmiri, 2010; Yazdi et al. 2017; Gardezi et al. 2021). Figure 1 shows the geological map of the Sourk mine area on a scale of 1:100,000.

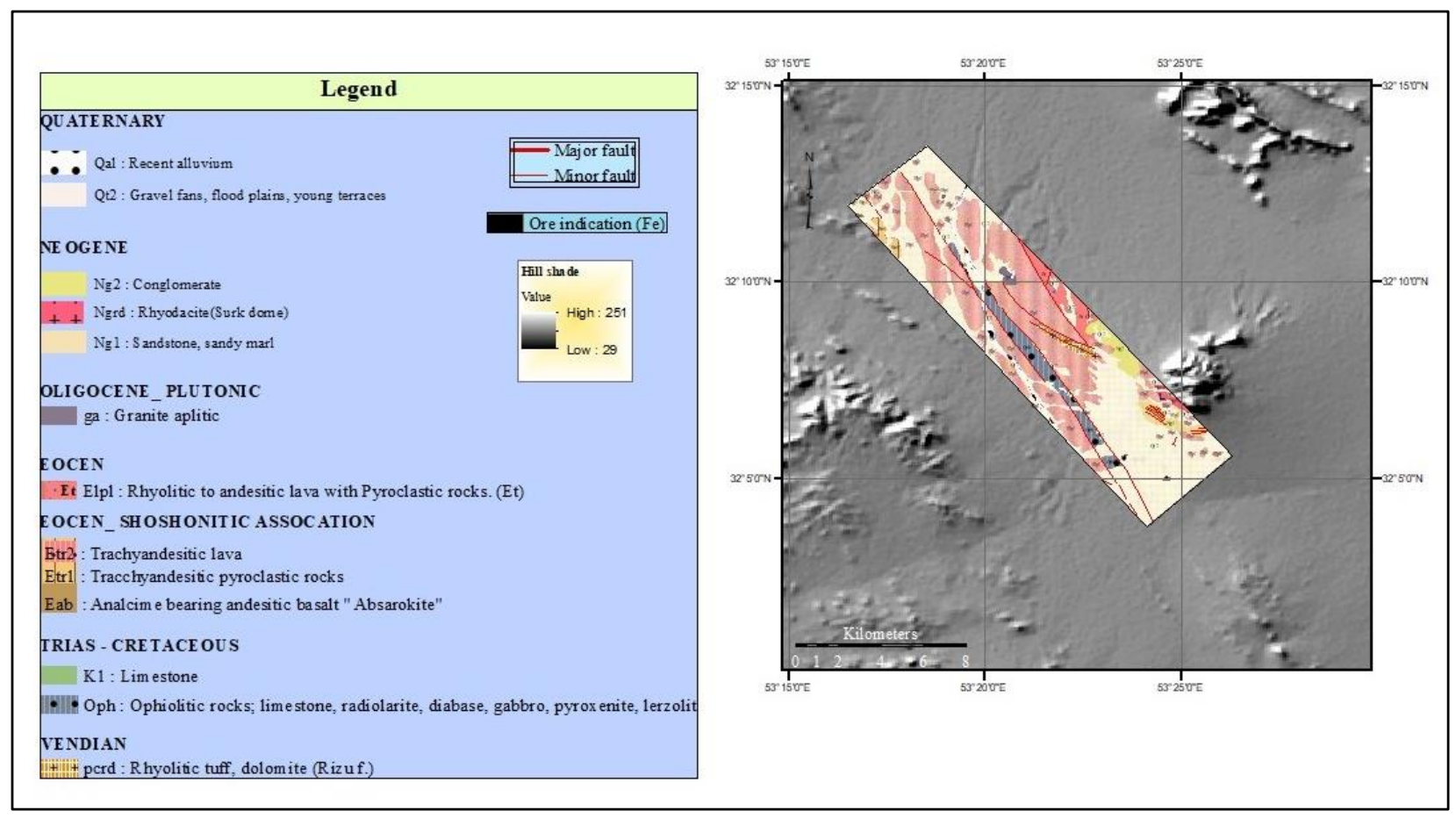

Figure 1. Geological map of Sourk mine, scale of 1:100,000 (Amidi, Nabavi, 1989)

\subsection{Geophysical Data}


The data used in this paper is airborne magnetic data of block C2 of Sourk mine from Dehshir zone, which was collected by the Geological Survey and Mineral Exploration of Iran in 2011 with flight line spacing of 250 meters and flight height of 40 meters using a single sensor helicopter. This area is located in a regional magnetic field with parameters including an inclination of 49.7 degrees, declination of 3.2 degrees, and IGRF 46658 nanoTesla.

\subsection{Reduction To Pole Transform}

Positive gravity anomalies tend to be located over mass concentrations, but the same is not necessarily true for magnetic anomalies when the magnetization and ambient field are not directed vertically. If the magnetization and ambient field are not vertical, magnetization's asymmetrical distribution will produce a "skewed" rather than a symmetrical magnetic anomaly. The transformed anomaly in the Fourier domain is given by the following formula:

$$
\mathrm{F}\left[\Psi \_\mathrm{r}\right]=1 /\left(\Theta \_\mathrm{m} \Theta \_\mathrm{f}\right)
$$

Where the "F[Y_r ]" is called reduction to the pole function and " $\Theta \_m$ " and " $\Theta \_f$ " are phase functions contributing to the phase of anomaly, depending on how the magnetization is distributed. Also these functions can shift the anomaly laterally, distort its shape and even change its sign (Blakely, 1995). At the latitudes between 20 to 70 degrees, due to the inclination and declination magnetic anomalies are recorded so that their relationship with the source of magnetism is asymmetric. Usually, the anomalies have kurtosis and a maximum peak of total magnetic intensity at the center of anomaly and their shape may also change slightly. By applying the reduction to pole transform, the total magnetic intensity of anomalies is symmetrical and placed on their pole's magnetic mass. Reduction to the equator is used for low latitude locations. In general, since given Iran is relatively high in magnetic latitudes, these filter results will be valid and useful. The total magnetic intensity (TMI) map with the reduction to pole filtration is shown in figure 2 . The final result of the filter is that the TMI data will be in the magnetic pole. If the filter's response causes a monopole, it might be a vertical dip of the magnetic anomaly. However, there are some conditions or limitations to interpret data concerning this filter:

1- It is not essential to utilize the remnant magnetization in data analysis; therefore, the induced magnetic field would be enough. If the anomaly is in the location where the remnant magnetization is considerable, the data analysis without it would be incorrect.

2- Reduction to the pole would not be correct for low magnetic latitude. In these regions, anomalies with north-south direction will be magnified and it will have impact on other anomalies (Cooper, \& Cowan, 2005) (Rajagopalan, 2003). 


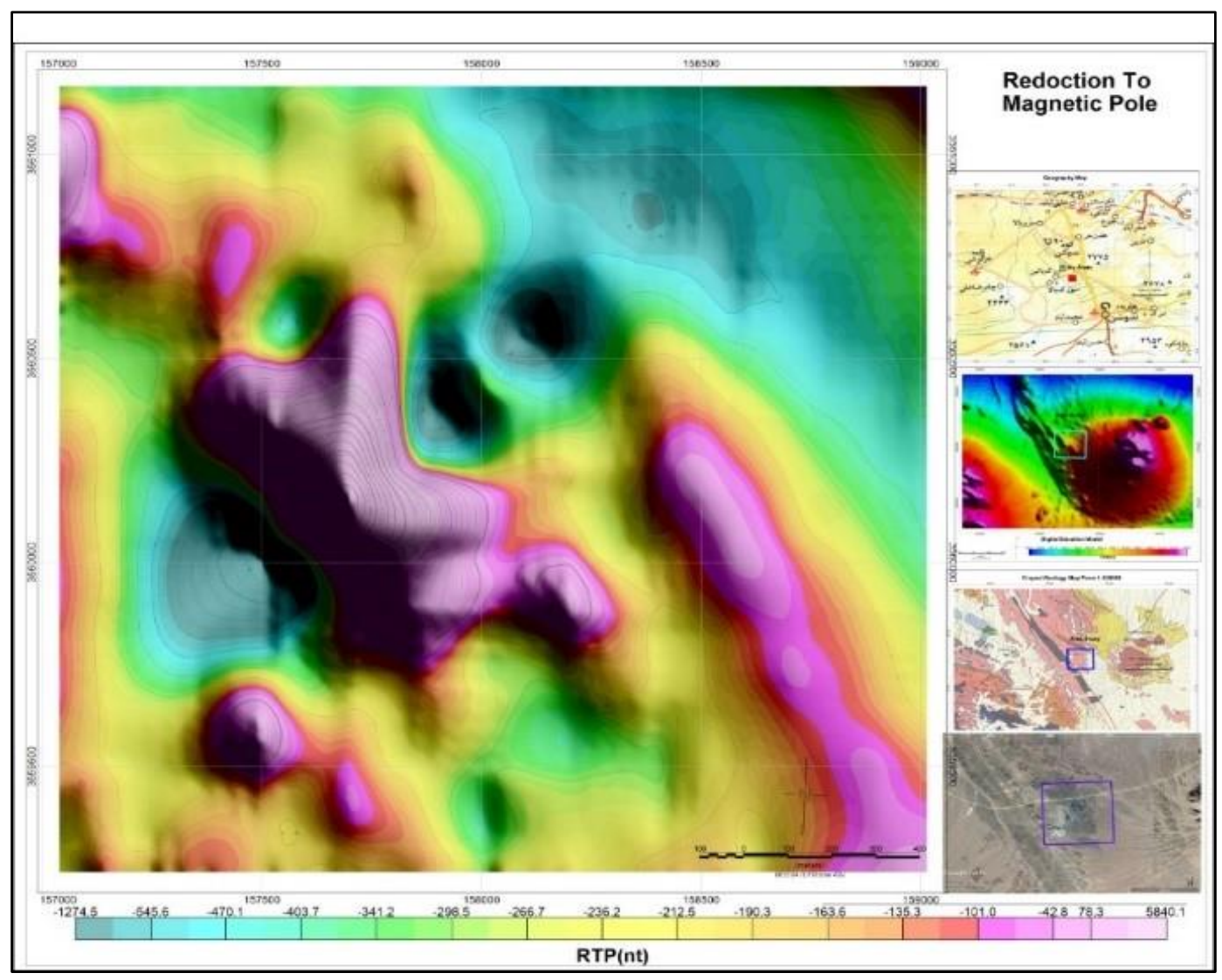

Figure 2. Total magnetic intensity with the reduction to pole filter

\section{DISCUSSION AND RESULTS}

\subsection{Inversion of Magnetic Data}

\subsubsection{Data Analysis}

This study aimed to inverse the determination of indicators from measurements. In geophysical studies in which Earth's gravity or magnetic measurements determine origin indicators, it is called the inverse method (Norouzi, 2009; Barahouei et al. 2021). During the geomodeling, the standard deviation of magnetic data is determined. The standard deviation of an estimate from all sources may cause uncertainty, including sensor sensitivity, noise, GPS location and modeling uncertainties of display of earth effects in the model and small magnetic sources that cannot be considered in the discrete making. The uncertainties set here for data are 1\% (Pilkington, 2009) ( $\mathrm{Li}, \&$ Oldenburg, 1996). These uncertainties are used in the UBC inversion problem to control the appropriate level of fitting observed data. This paper presents geomodeling with the inversion method in comparison to drilling holes data. Followed by, the magnetic data is inversed using the INVERSE UBC-GIF MAG3D program by 3D susceptibility modeling. Data is converted to UBC ASCII DATA format of software input format for incoming operations. Figure 3 displays the distribution of uncertainty data along with the initial model. 


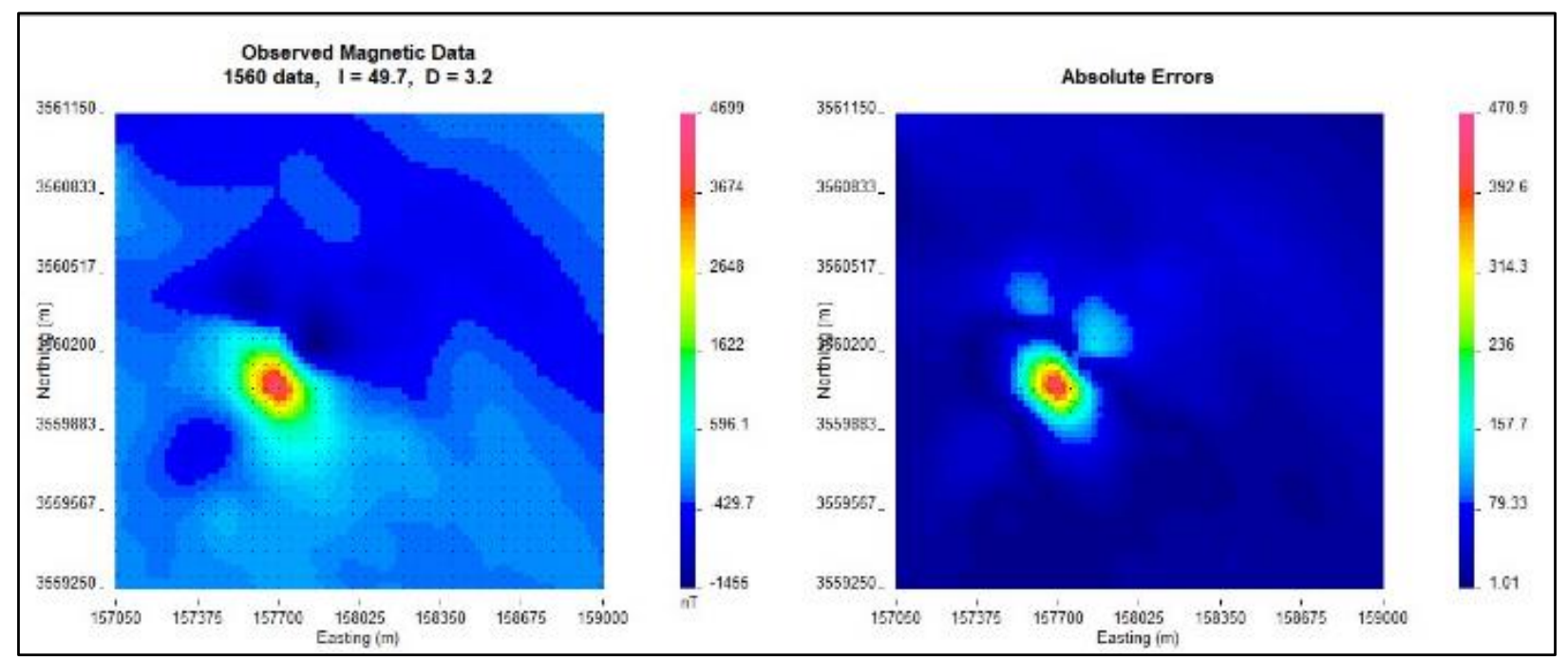

Figure 3. Distribution of uncertainty of data error with initial geomodeling data

\subsubsection{Inversion Results}

For geomodeling, the range of anomalies is divided into an $11 \times 227 \times 102$ network of rectangular cells. The length, width, and height of each cell according to the initial processing performed using Geosoft software in the north-south direction are 10 meters and 10 meters respectively, and to increase the depth up to 340 meters, it is 5 meters. After implementing the inversion process, the program has reached optimal convergence with 64 repetition sequences. Based on susceptibility, the 3D shape of the final model is plotted using MeshTools3D software. Figures 4 and 5 display the model of the susceptibility of a top view of 90 and 140 meters depths, which susceptibility at center is higher at depths of 90 and 140; whereas, the susceptibility decreases by arising depth to more than 300 meters. Figures 6 and 7 depict the cross and long sections of the model at different depth levels. According to figure 8, the maximum susceptibility is related to igneous and magnetite rocks and the susceptibility of magnetite start from 0.3 to above according to its purity percentage (Dunlop, 1974). There are many rectangular cells with susceptibility above 0.2 ; when the distance from the center of anomaly boosts, the amount of susceptibility will fall. According to the 3D models of Figures 9 and 10, this mass's depth expansion is estimated at 325 meters based on magnetite's susceptibility difference. From this depth to the bottom, the amount of susceptibility has been reduced, representing non-magnetic rocks. 


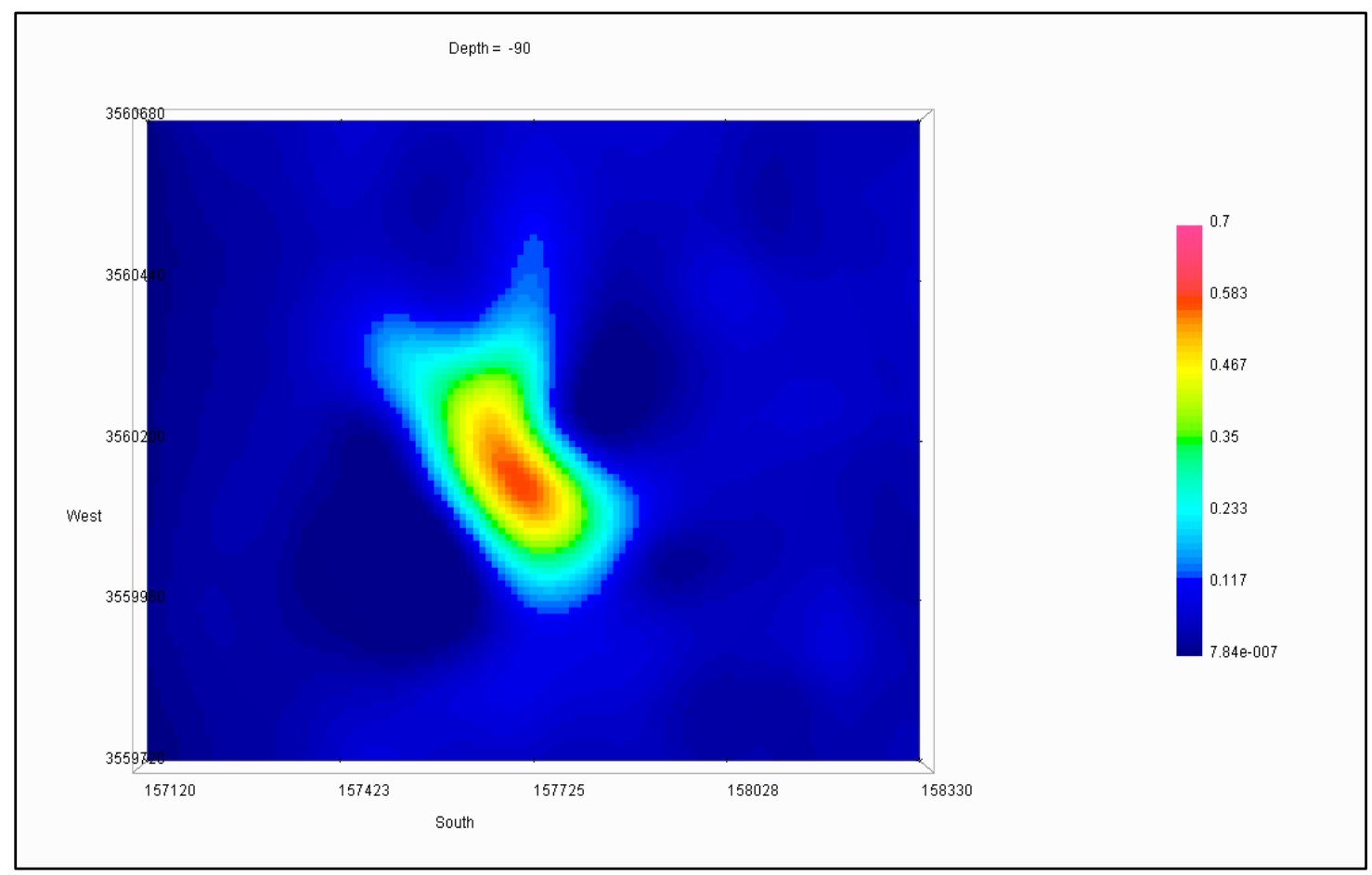

Figure 4. The obtained 3D model at depth of 90 meters

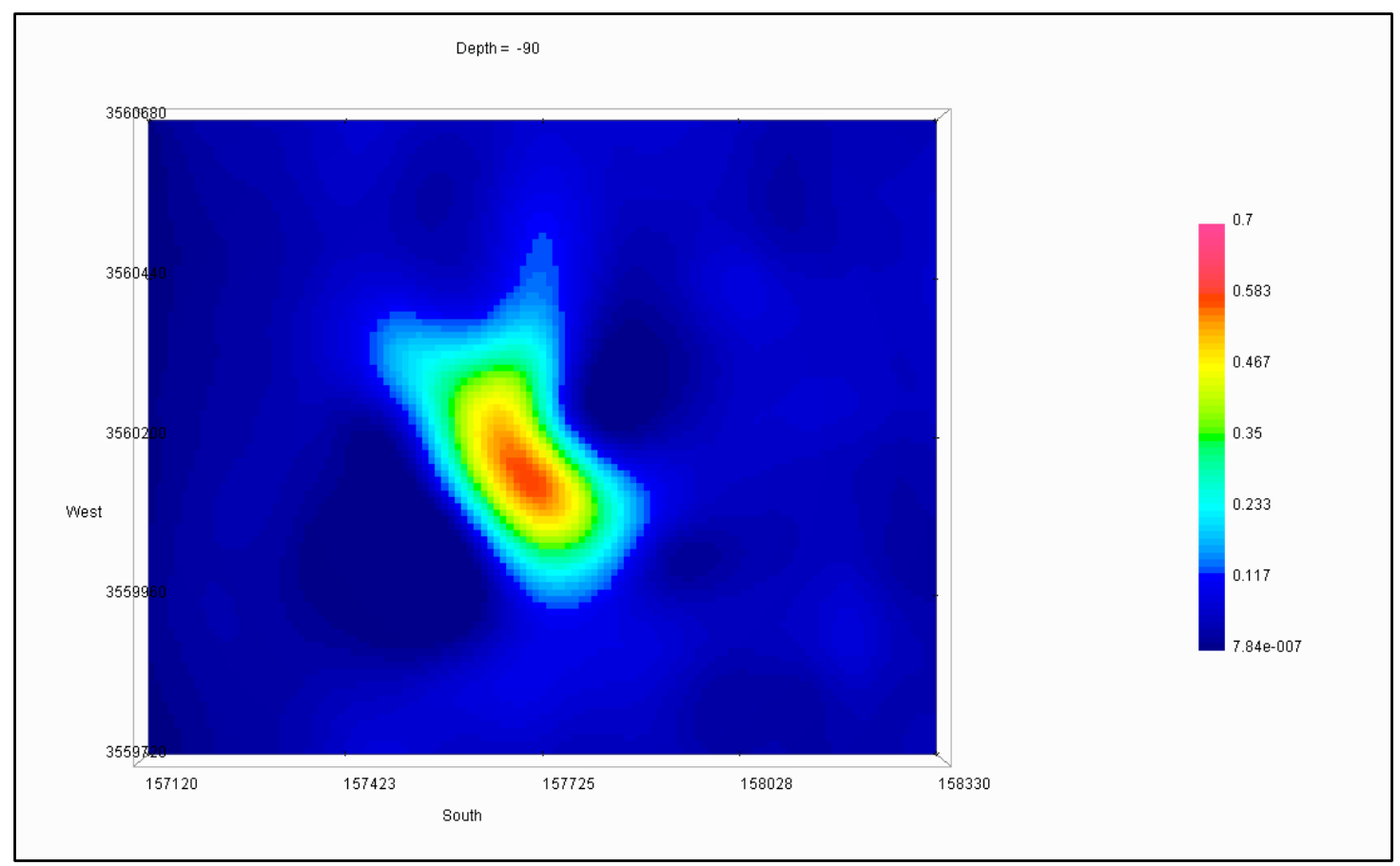

Figure 5. The obtained 3D model at depth of 140 meters 


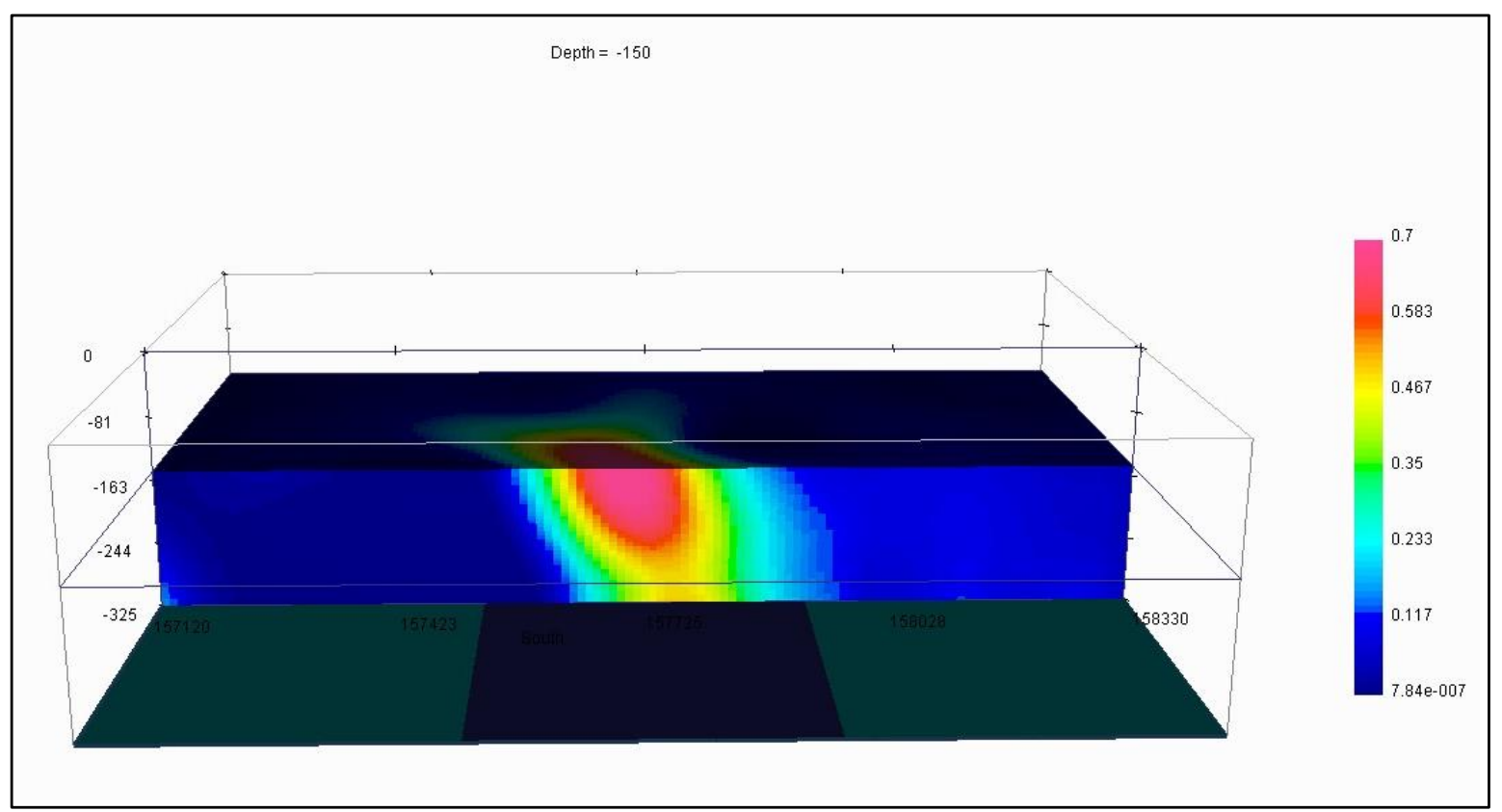

Figure 6. Cross-section of the 3D model at latitude of $Y=3560150$ at depth of 150 meters

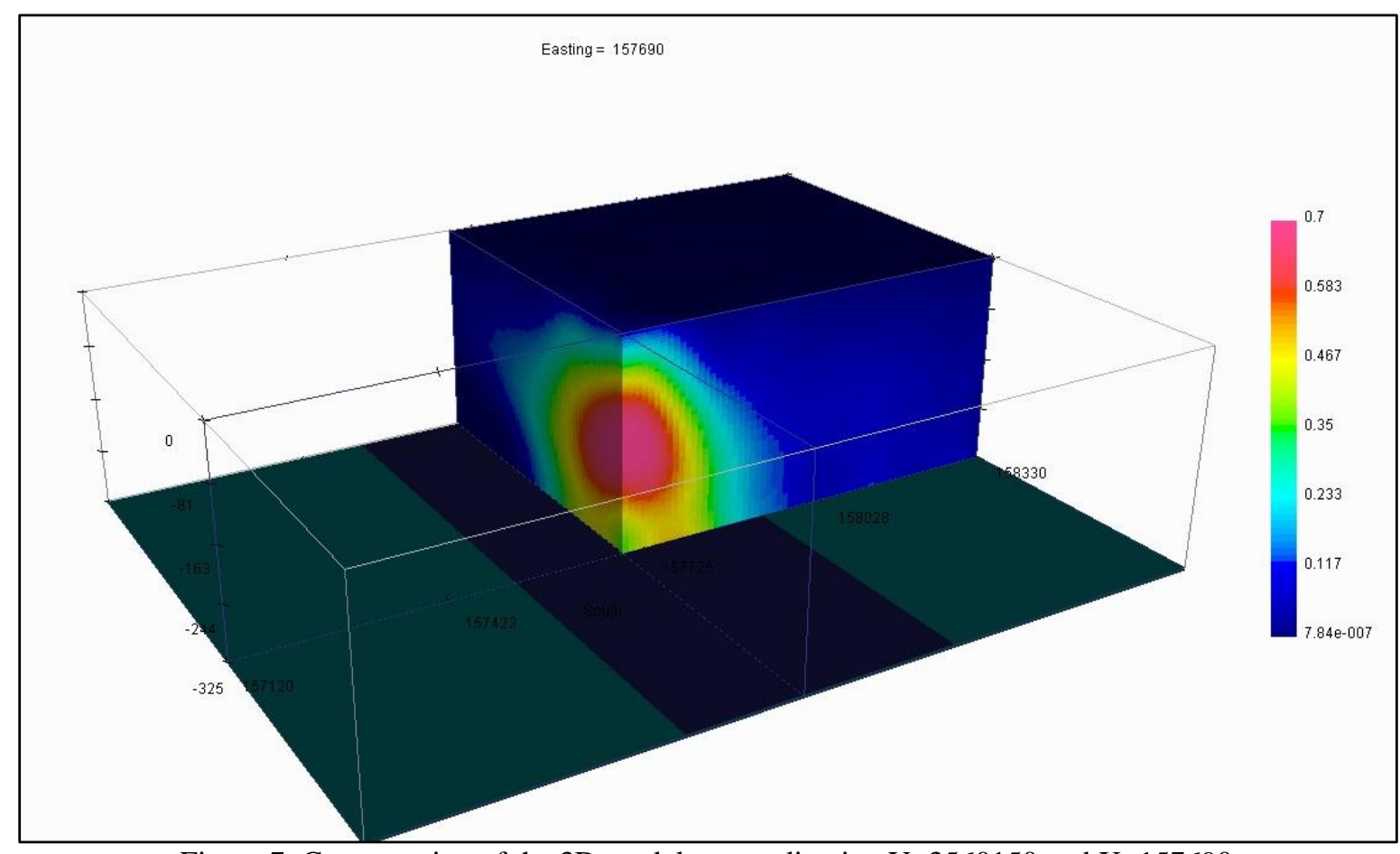

Figure 7. Cross-section of the 3D model at coordination $Y=3560150$ and $X=157690$ 


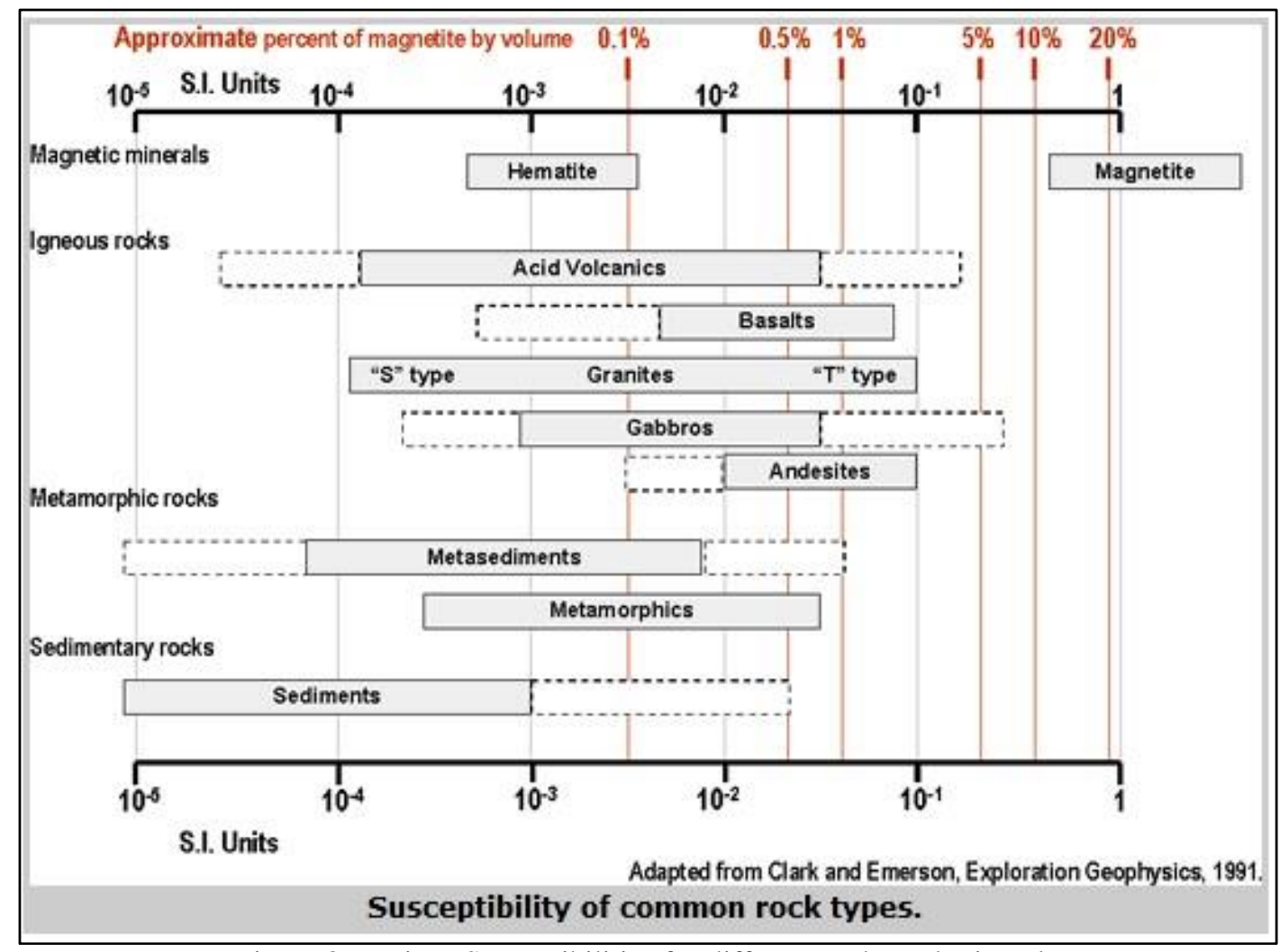

Figure 8. Various Susceptibilities for different rocks and minerals

Another display of modeling results is the Cutoff display, where the effects that are not targeted have been eliminated. This type of display is a better feature for demonstrating and calculating potential magnetic volumes. Figure 9 shows cutoff horizontal cross-section at depth of 100 meters. As that figure shows, the susceptibility response less than 0.3 are excluded from the data set display. In this figure it is obvious that the maximum susceptibility is related to the center of the mass and with distance from the center, the amount of susceptibility and the percentage of magnetite decrease. In Figure 10, the Mesh grid schema of this 3D model is shown for better display of center of the anomaly. 


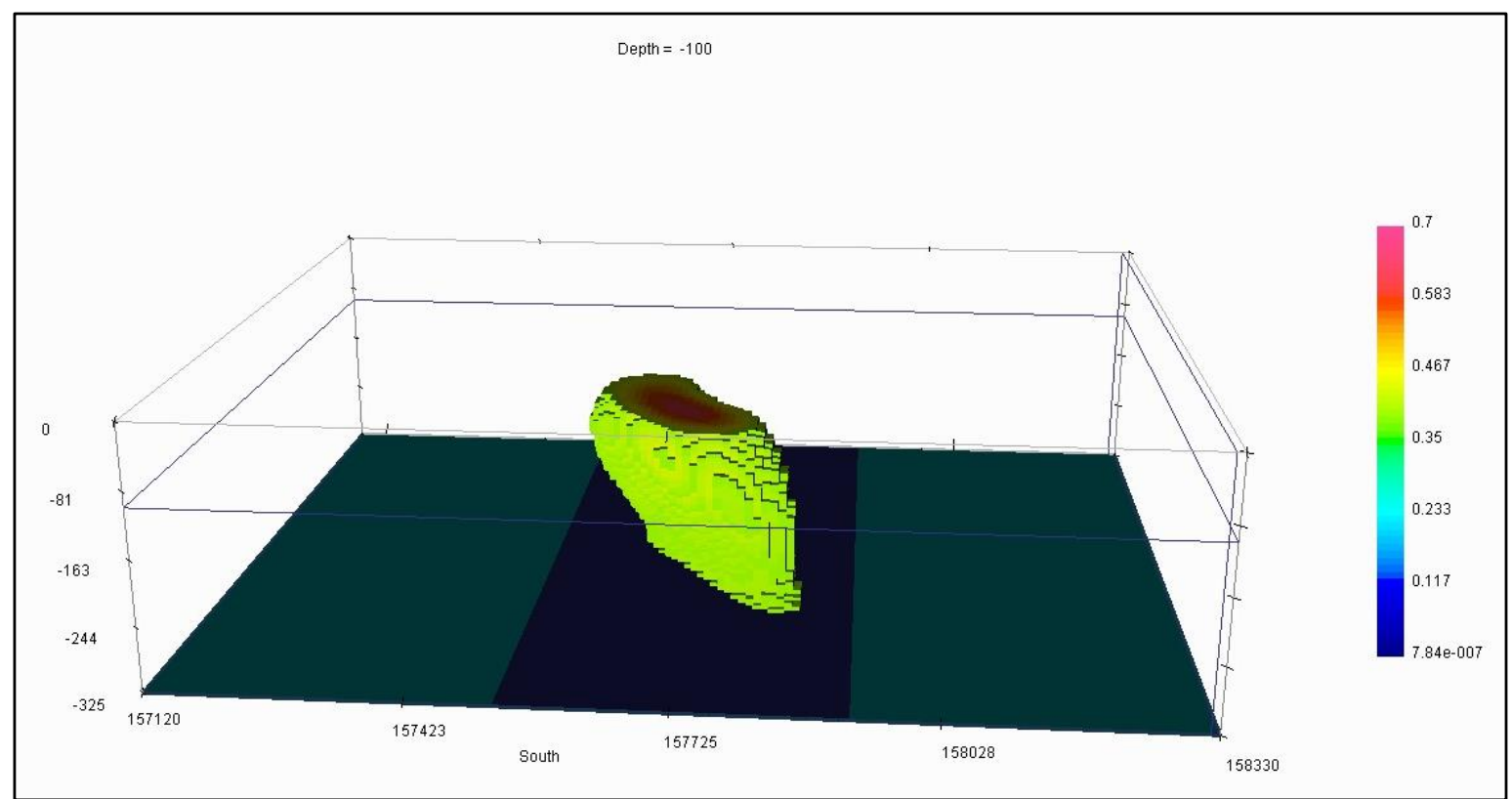

Figure 9. 3D view of the Cutoff model with a depth cut off 100 meters

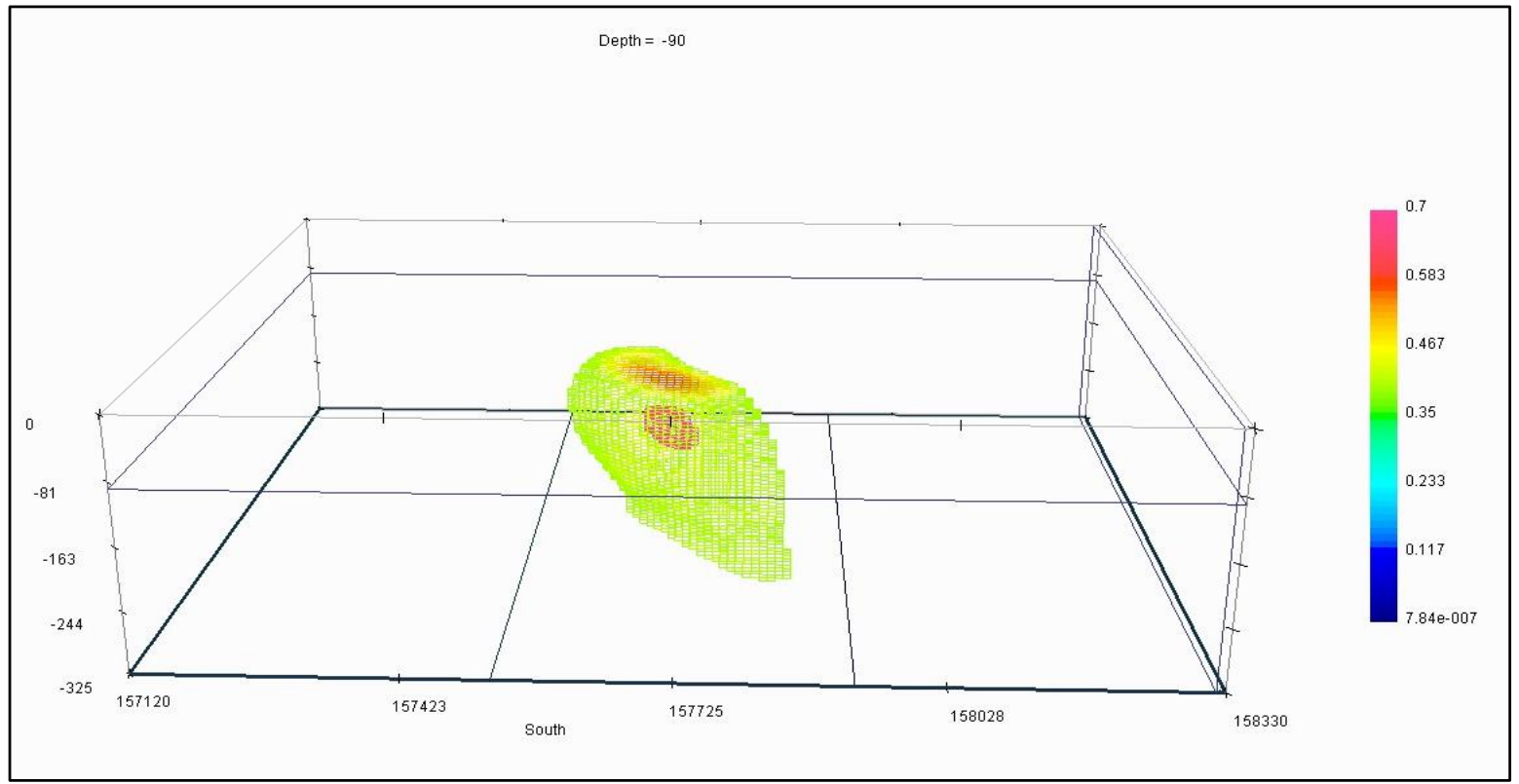

Figure 10. Mesh display of 3D model at a depth cross-section of 90 meters

\subsection{D model based on the drilling data}

Exploration drilling in the Sourk iron ore mine started systematically afterwards and 49 boreholes were proposed for this area based on the geophysical method model. The locations of boreholes are shown in figure 11 . The Sourk iron ore exploration network has been carried out based on geophysical studies conducted in the ore deposit region and geological characteristics. According to geological and geophysical studies, the initial drilling network's dimensions were considered to 
be $50 \times 50$ meters. By drilling and analyzing each borehole's results, in some cases, the drilling network dimensions were inevitably changed, and its dimensions reached about $25 \times 25$ meters in some places.

As stated before, inevitably due to changes in condition of the ore, the determined drilling network had to be out of the designed order in dimension and spacing at some points. Borehole modeling was performed using GEMCOM software. Figure 12 shows the vertical section of the model with its depth and the boreholes' location in this model. Figure 13 shows the cutoff model and the depth of mineralization is also shown in the model. In figures 14 and 15, the cutoff 3D model with pit crater and horizontal surface of the magnetic field intensity are shown.

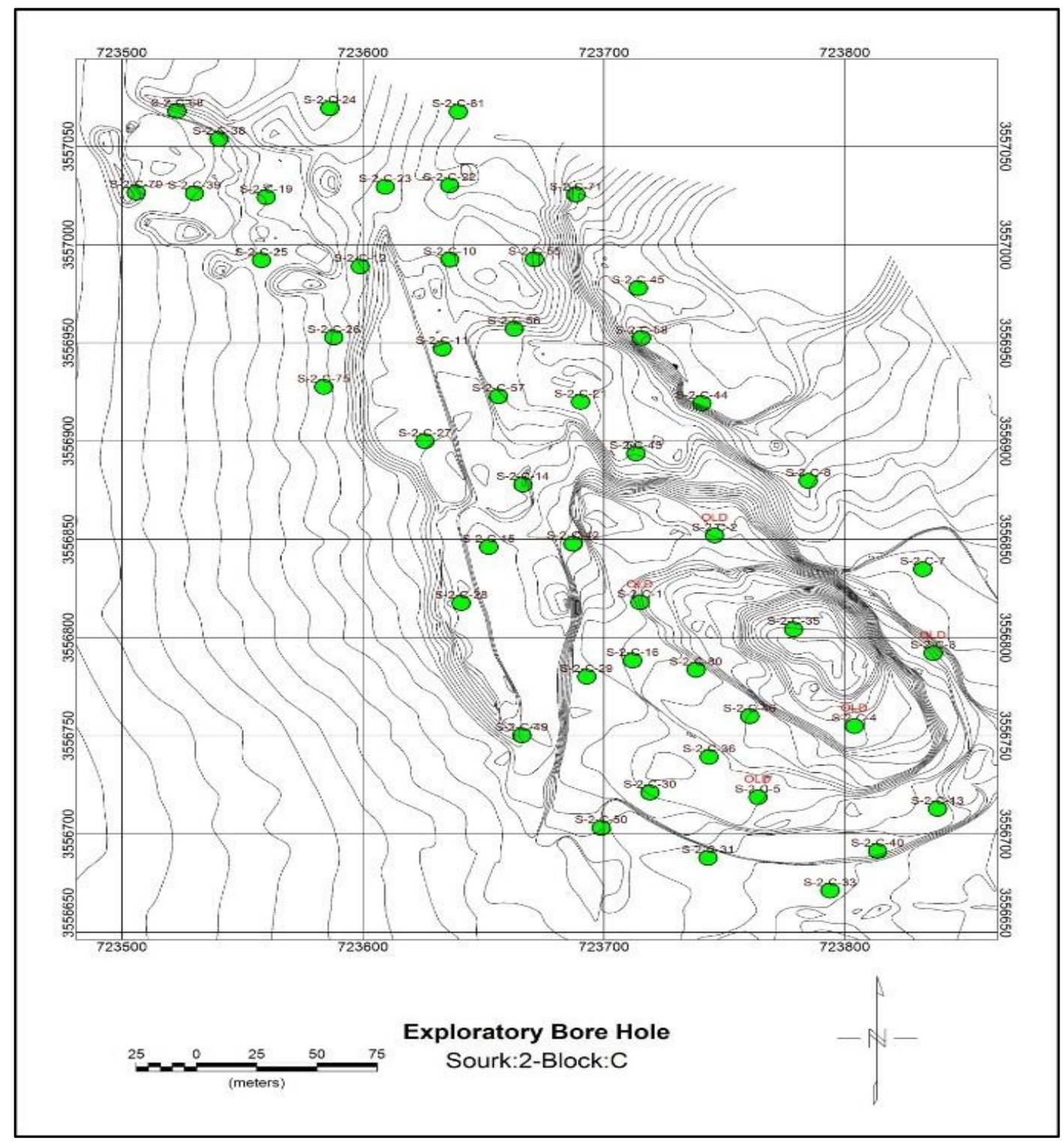

Figure 11. Location of proposed drilling points based on geophysical data modeling results 


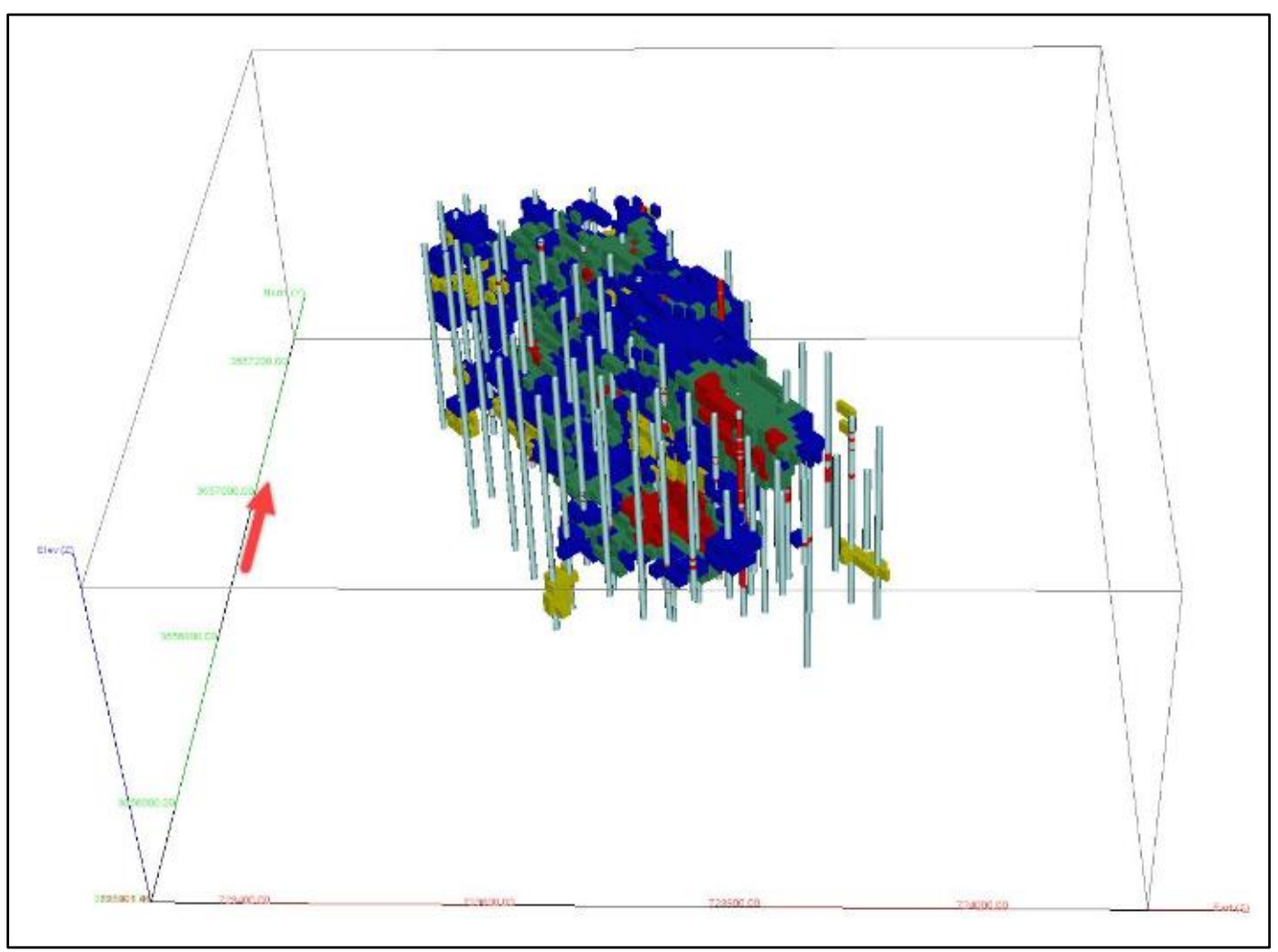

Figure 12. Vertical-section

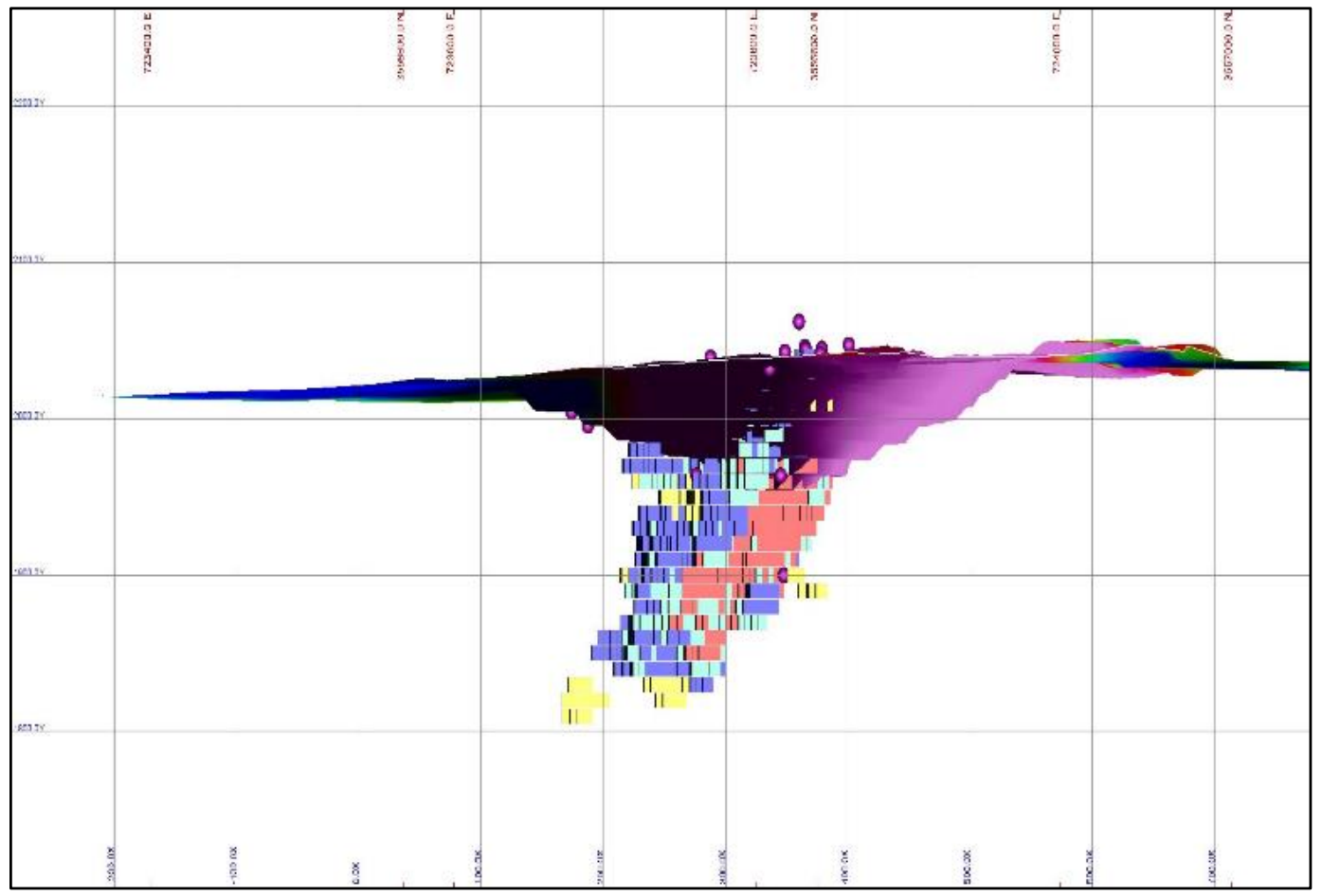

Figure 13. Cutoff model 


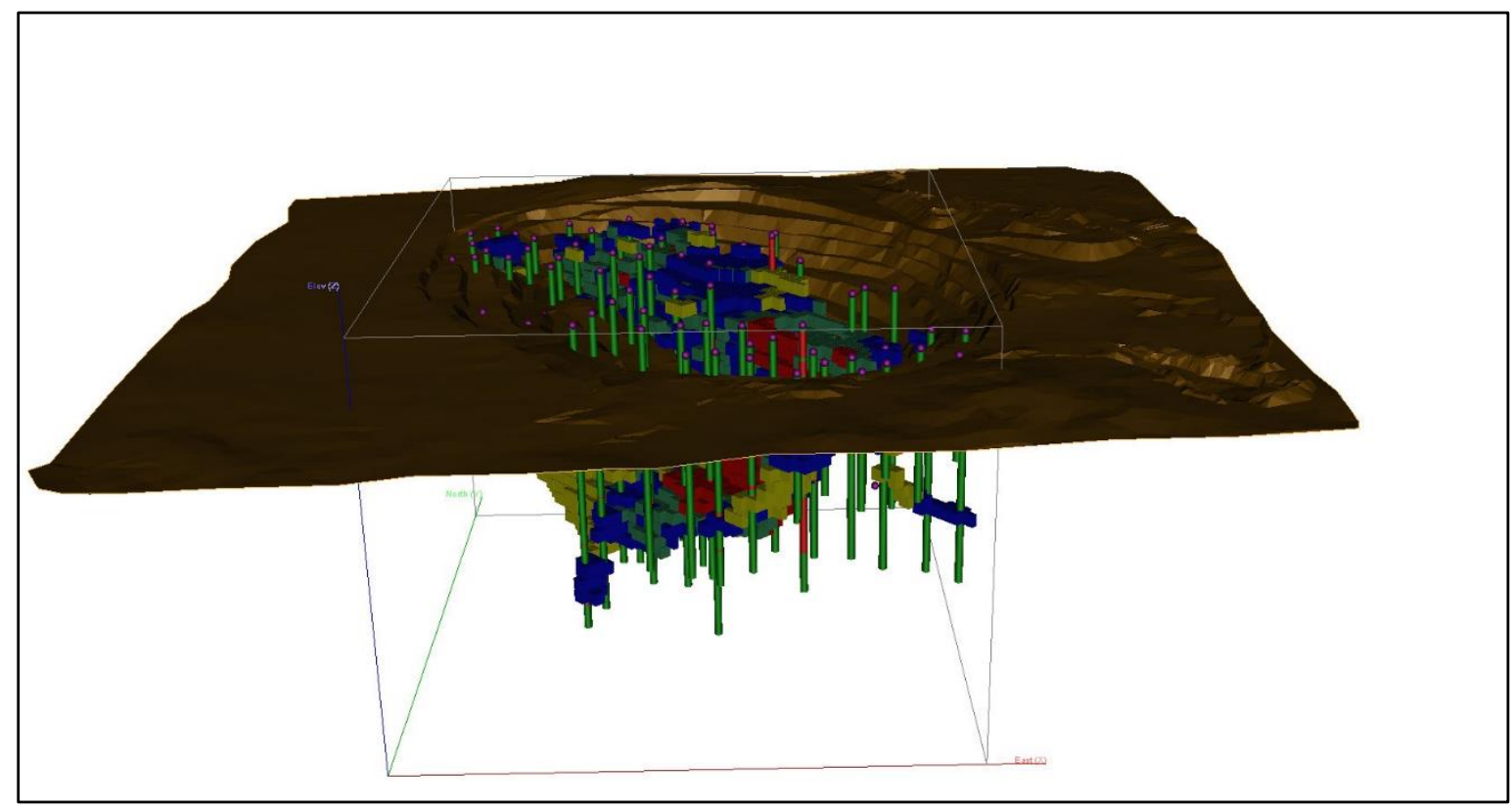

Figure 14. geomodeling with the position of the borehole and the pit crater model

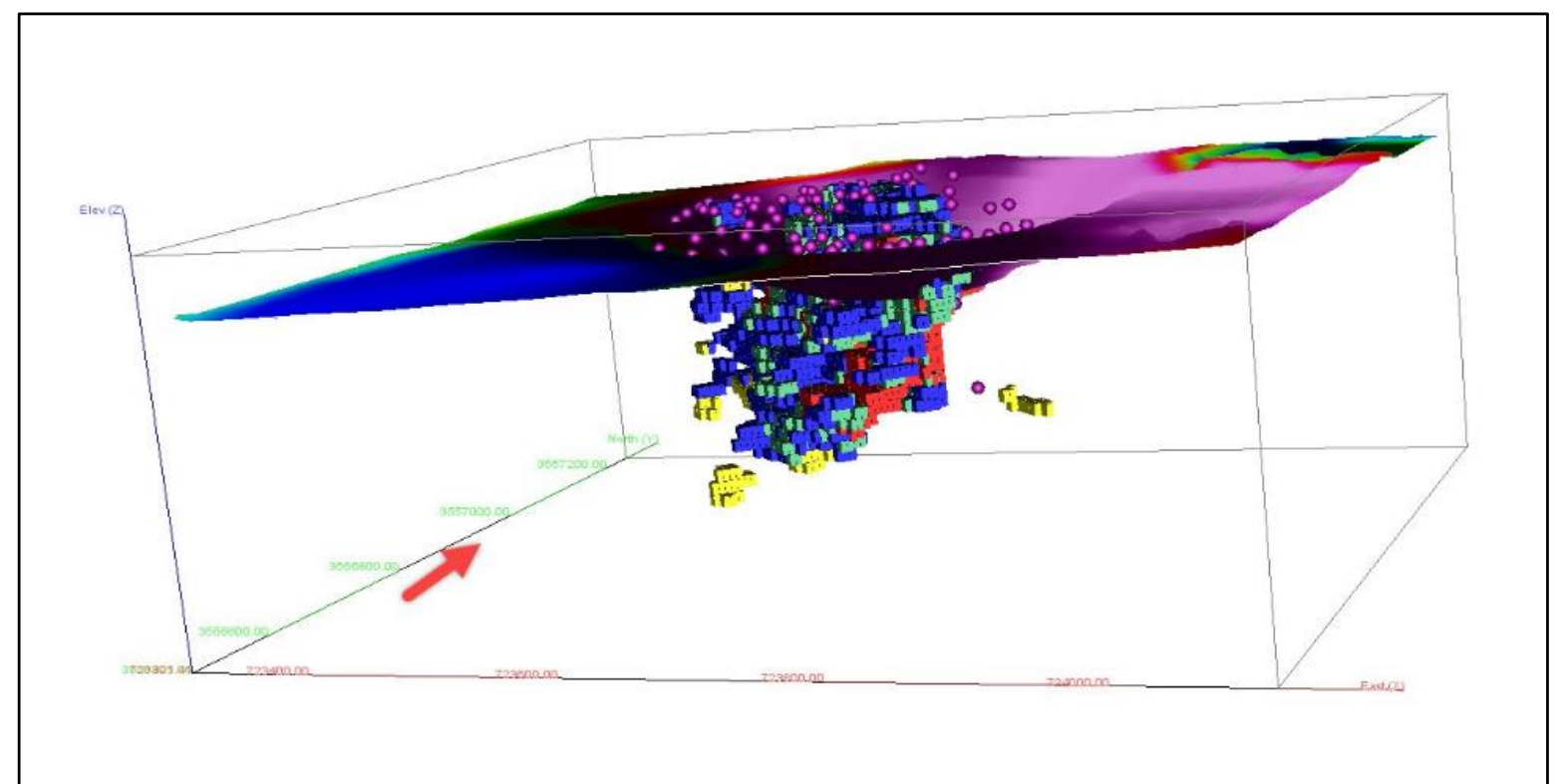

Figure 15. 3D modeling of boreholes with the horizontal plane of magnetic field intensity from data by the cutoff display method

\section{CONCLUSIONS}

In this study, 3D modeling of the Sourk skarn iron deposit's block $\mathrm{C} 2$ based on airborne magnetic data was conducted. The resulting model consists of a cubic network of cells, each of which has an assigned value of magnetic susceptibility. According to the results of the 3D model, the drilling points were suggested. Based on the 3D model resulting from geophysical data, the center of the model has the highest susceptibility and this value decreases with the distance from the center. The susceptibility values less than 0.25 have been excluded from the results because these susceptibility 
values are related to low percentage assay magnetite. The homogenic distribution of susceptibility must opt for as a default. After 3D modeling of geophysical data, drilling points were defined based on the obtained model and drilling operations were performed. In terms of the ore deposit model's shape derived from the boreholes data, the geomodeling with Inversion method adapted with drilling data model very well. The results of modeling using Gemcom software are shown in Table 1. In general, according to the table, the estimated tonnage is $13400000 \mathrm{~kg}$ and confirms the results of the geophysics method by similar shape and dimensions of the two models. Finally, it is recommended for assessing geometry of ore body such as its strike and structural index, investigation of the situation of noises of other mineralization on top of the overburden of this anomaly with both geological data from drilling boreholes and magnetic data set to be carried out. Moreover, Euler deconvolution, three-dimensional analytical signal, tilt angle and NSS method would be beneficial to improve the accuracy of estimation.

Table 1. Results of borehole geomodeling

\begin{tabular}{|c|c|c|c|c|}
\hline $\begin{array}{c}\text { Classification of } \\
\text { Reserve }\end{array}$ & $\begin{array}{c}\text { Average } \\
\text { Concentration }(\%)\end{array}$ & $\begin{array}{c}\text { Volume of } \\
\text { Reserve }\left(\mathrm{m}^{3}\right)\end{array}$ & $\begin{array}{c}\text { Density of } \\
\text { Reserve }\left(\text { tonne } / \mathrm{m}^{3}\right)\end{array}$ & $\begin{array}{c}\text { Tonnage of } \\
\text { Reserve }\end{array}$ \\
\hline Proved & 49.86 & 2343750 & 3.91 & 9164063 \\
\hline Possible & 39.67 & 1206250 & 3.56 & 4294250 \\
\hline Probable & 27.85 & 187500 & 3.2 & 600000 \\
\hline
\end{tabular}

\section{REFERENCES}

Adewumi, T., Adeyinka Salako, K., Defyan Alhassan, U., Abbass Adetona, A., Adewuyi Rafiu, A., Emeka Udensi, E. (2021). Interpretation of Airborne Radiometric data for possible hydrocarbon presence over Bornu basin and its environs, Northeast Nigeria using Thorium normalisation method, Iranian Journal of Earth Sciences, 13(3): 161-172. doi: 10.30495/ijes.2021.682863

Amidi, M., \& Nabavi, M.H. (1989). Geological Map of Sarve bala scale 1:100,000. Tehran, Iran: Geological Survey of Iran.

Barahouei, B.A., Noura, M.R., Moslempour, M.E., Dabiri, R. (2021). Evaluation of groundwater suitability for the domestic and irrigation purposes in Konaro Ophiolitic Area, Iranshahr, SE Iran, , Iranian Journal of Earth Sciences, 13(3): 196-208. doi: 10.30495/ijes.2021.682867

Baratian, M., Arian, M.A., Yazdi, A. (2020). Petrology and Petrogenesis of Siah Kooh Volcanic Rocks in the Eastern Alborz. Geosaberes, 11: 349-363

Bazoobandi, M.H., Arian, M.A., Emami, M.H., Tajbakhsh, G., Yazdi, A. (2016). Petrology and Geochemistry of Dikes in the North of Saveh in Iran, Open journal of marine science, 6(02): 210-222.

Blakely, R.J. (1995). Potential Theory in Gravity and Magnetic Applications. Cambridge, United Kingdom: Cambridge University press. doi:10.1017/CBO9780511549816

Cooper, G.R.J., \& Cowan, D.R. (2005). Differential reduction to the pole. Computers \& Geosciences, 31(8), 989-999. doi:10.1016/j.cageo.2005.02.005 
Dunlop, D.J. (1974). Thermal enhancement of magnetic susceptibility. Journal of Geophysics, 40(1), 439451. Retrieved from https://journal.geophysicsjournal.com/JofG/article/view/162

Gardezi, S.A.H., Ahmad, S., Ikram, N., Rehman, G. (2021). Geological constraints on the Western Kohat foreland basin, Khyber Pakhtunkhwa, Pakistan: Implication from 2D and 3D structural modelling, Iranian Journal of Earth Sciences, 13(2): 61-76. doi: 10.30495/ijes.2021.678954

Li, Y., \& Oldenburg, D.W. (1996). 3-D Inversion of magnetic data. Geophysics, 61(2), 394-408. doi:10.1190/1.1443968

Makkizadeh, M.H., Rahgoshay, M., \& Daliran, F. (2007). Formation of andradite grona in Sourk iron skarns at Nain-Sourk ophiolitic band. Science Research Journal of Isfahan University, 27(1), 157-167. Retrieved from https://www.sid.ir/fa/Journal/ViewPaper.aspx?ID=67318

Moghadam. A.R., Lotfi, M., Jafari, M.R., Ashja Ardalan, A., Moghaddam, M.P., Yazdi, A. (2021). Economic Geology, Petrology and Environmental of Copper Ore Deposits of Chagho in South West Karaj, Revista Geoaraguaia 11 (1), 7-26

Norouzi, Gh. (2009). Exploration Geophysics. Tehran, Iran: University of Tehran Press.

Oldenburg, D.W., \& Pratt, D.A. (2007). Geophysical inversion for mineral exploration: A decade of progress in theory and practice. Proceedings of Exploration 07: Fifth Decennial International Conference on Mineral Exploration, 61-95. Retrieved from https://www.researchgate.net/publication/285117728_Geophysical_inversion_for_mineral_exploration_A _decade_of_progress_in_theory_and_practice

Pilkington, M. (2009). 3-D Magnetic data-space inversion with sparseness constraints. Geophysics, 74(1), L7-L15. doi:10.1190/1.3026538

Rajagopalan, Sh. (2003). Analytic Signal vs. Reduction to Pole: Solutions for Low Magnetic Latitudes. ASEG Extended Abstracts, 2003(2), 1-4. doi: 10.1071/ASEG2003ab136

Reihany, M., Noori, K., Karimi, M. \& Ghetmiri, H., (2010). A Petrographic Study of Sourk Iron Mine, Yazd. Conference on Applied Petrology, 1(1), 1-8. Retrieved from https://www.sid.ir/fa/seminar/ViewPaper.aspx?ID=6217

Shafaii Moghadam, H., Stern, R.J. \& Rahgoshay, M., (2010). The Dehshir ophiolite (central Iran): Geochemical constraints on the origin and evolution of the Inner Zagros ophiolite belt. GSA Bulletin, 122(910), 1516-1547. doi:10.1130/B30066.1

Ullah, H., Khalid, P., Mehmood, M., Ahmed Mashwani, S., Abbasi, Z., Jehangir Khan, M., Ul Haq, E., Mujtaba Shah, G.H. (2021). Reservoir potential, net pay zone and 3D modeling of Cretaceous Pab Formation in Eastern Suleiman Range, Pakistan, Iranian Journal of Earth Sciences, 13(3): 173-180. doi: 10.30495/ijes.2021.682864

Yazdi, A., Ashja-Ardalan, A., Emami, M.H., Dabiri, R., Foudazi, M. (2017). Chemistry of Minerals and Geothermobarometry of Volcanic Rocks in the Region Located in Southeast of Bam, Kerman Province. Open Journal of Geology, 7(11), 1644-1653 
Yazdi, A., Ashja-Ardalan, A., Emami, M.H., Dabiri. R., Foudazi, M. (2019). Magmatic interactions as recorded in plagioclase phenocrysts of quaternary volcanics in SE Bam (SE Iran), Iranian Journal of Earth Sciences, 11(3): 215-224. doi: http://ijes.mshdiau.ac.ir/article_667379.html

Yazdi, A., Sharifi Teshnizi, E. (2021). Effects of contamination with gasoline on engineering properties of fine-grained silty soils with an emphasis on the duration of exposure, Springer, SN Applied Sciences, 3:704. doi: https://doi.org/10.1007/s42452-021-04637-x 